\title{
Theoretical considerations of the innovation concept and case study - innovation in a food producing firm
}

Considerações teóricas do conceito de inovação e estudo de caso - a inovação em uma empresa de produção de alimentos

\author{
Knut Ingar Westeren \\ Nord- Trøndelag University College
}

\begin{abstract}
In this article there is first an introduction about how concepts like entrepreneurship, innovation and creative destruction were developed by Schumpeter at the beginning of the $20^{\text {th }}$ century. Schumpeter wanted to analyze the big questions about how the capitalist system developed based on a disequilibrium foundation. His concepts were necessary to develop his general theory of development, but at the same time these concepts have been adopted, used and developed for the analysis of one of the most important economics concepts for the $21^{\text {th }}$ century, namely, innovation. Schumpeter used his concepts in relation to firms, to sectoral developments and for the economy as a whole. In this article we use a case study of innovation and we find relevance from Schumpeter's analysis and further developments of innovation theory.
\end{abstract}

Keywords: Innovation; Entrepreneurship; Creative destruction; White meat production.

Resumo: Neste artigo faz-se primeiro uma introdução sobre como conceitos como empreendedorismo, inovação e destruição criativa foram desenvolvidos por Schumpeter no início do século 20. Schumpeter quiz analisar uma questão importante de como o desenvolvimento do sistema capitalista baseou-se na pressuposicao do desequilíbrio. Seus conceitos foram necessários para desenvolver sua teoria geral do desenvolvimento, mas, ao mesmo tempo, esses conceitos têm sido adotados, usados e desenvolvidos para a análise de um dos mais importantes conceitos de economia do século 21 denominado inovação. Schumpeter usou esses conceitos em relação a empresas, desenvolvimento setorial e para a economia como um todo. Neste artigo foi utilizado um estudo de caso de inovação e foi encontrada relevância da análise schumpeteriana e novos desenvolvimentos da teoria da inovação.

Palavras-chave: Inovação; Empreendedorismo; Destruição criativa; Produção de carne branca.

JEL: $\mathrm{O}_{31}$

\section{Innovations - a central concept for economic analysis and development}

The discussions and analysis of the concepts entrepreneurship and innovation have been one of the most focused and fundamental themes in scientific research and economic policy in recent decades. It is interesting also to observe the extensive attention these concepts have gotten from the public and media more in general. Today the innovation concept is used in many circumstances and in many connections; we have literature on business innovation, on regional and national innovation systems and on innovation in the public sector. We also have discussions about innovation and entrepreneurship as some of the most important initiatives of industrial policies in Europe, USA and the rest of the world.

The scientific literature and applied projects centered around innovation and entrepreneurship often relate back to the work of Joseph A. Schumpeter and his three famous books, The Theory of Economic Development (1934), Business Cycles (1939) and Capitalism, Socialism and Democracy (1942/1950). In this article we first want to give a presentation of how Schumpeter developed concepts like the entrepreneur, innovation and creative destruction and see how this fits into his more general analysis of capitalist development. We must be aware of the fact that Schumpeter does not use the word innovation very often; he speaks more about entrepreneurial

Informe Gepec, Toledo, v. 18, n. 2, p. 163-176, jul./dez. 2014 
activities, new combinations and creative destruction. After the theoretical discussions we will look at how a company in the food processing sector is able to do innovating activities and how these innovations can be linked to the original concepts.

\section{Innovations - what can we learn from Schumpeter?}

Schumpeter's project was to analyze the main questions about the development of the capitalistic system. His work became what we can call a third direction in economic theory in the first part of the $20^{\text {th }}$ century; the first is neoclassical equilibrium theory building on Walras and the second is Marxian economic theory. Schumpeter started his scientific writings around 1900 and in 1911 he published his first main book in German, "Theorie der wirtschaftlichen Entwicklung", Schumpeter (1911). The first German edition of this book was much longer and had one chapter that was not included in the English translation of the book that came later called, "The Theory of Economic Development", Schumpeter (1934). The main idea with this book, and which continues in most of his later scientific production, is to establish a theory of disequilibrium based on the foundations of the capitalist economy where the market as an institution plays an important role together with private ownership. Schumpeter fundamentally disagreed with Walras who believed that capitalist economies would develop into an equilibrium situation. On the other hand, Marxian economics was based on disequilibrium development but it had a fundamental critique of the capitalist market system built upon the analysis which Schumpeter rejected.

If we look at the time period from 1860 to 1910 it is easy to observe that the capitalist economy in Europe had gone through many upward and downward fluctuations and the decline of the development had represented a crisis in income for many groups which gave rise to the ideology of socialism. Schumpeter wanted to show that disequilibrium development was a natural tendency for the capitalist economy and this could temporarily produce a decrease in income. But in the longer run this would lead to a renewal of the production structure and an economic surplus for the population.

When we look at the work of Schumpeter he often uses examples from production sectors and individual firms, but we must remember that his primary reasoning had the economic system as the point of departure. This can be understood just by looking at the title of his first book in the English translation where he uses the word "Development". Schumpeter says that development is what we are getting when we look at what is arising from initiatives within the economic system, Schumpeter (1911/2002). The alternative to development is what Schumpeter calls adaptation, which is from his point of view, changes that are not qualitatively new and that (normally) emerge in response to forces outside the economy.

It is interesting to see how the use of the innovation concept that started in the German version of the book from 1911, is still taken into account when Schumpeter develops his central concepts of entrepreneurship, innovation and creative destruction. Schumpeter, in his book about "Development", also expresses the point of view that what he refers to as ordinary economic theory (what we today would call neoclassical economics) is not capable of explaining economic development. The way Schumpeter links his concepts together is that when he introduces the term entrepreneur it is for the economic actor who causes development. Schumpeter also 
gives some arguments about the principle of rational behavior that he says works perfectly well when the situation is like the static economy. However, when we have the introduction of something new, then rational behavior in the traditional way will not always give the logically correct answer.

When we come to what creates development, the theory of Schumpeter is individualistic. In the 1911 edition of "Theorie" he explains about the man of action (Man der Tat) and describes him as someone who does not accept reality as it is. It is this man of action that defines the entrepreneur. Schumpeter formulates it like this:

"He (the man of action) takes pleasure in a social power position and in creating", Schumpeter (1911), cited after Svedberg (2007).

And now we come to the famous part of Schumpeter's theory that says that the person who makes the new combinations is the entrepreneur. The use of the expression "new combinations" is central for Schumpeter. When we look at entrepreneurs, from Thomas Edison to Steve Jobs, they all are faced with a large number of possible combinations. But the central ability of the entrepreneur is to choose the right combinations and make them a reality in a system that is the firm. In Schumpeter's English version of the book, "Theory of economic development" from 1934, p 66, we find his list of the types of new combinations which he links to innovation:

1. The introduction of a new good or a new quality of a good.

2. The introduction of a new method of production which need by no means to be founded upon a scientifically new discovery, and can also exist in a new way of handling a commodity commercially.

3. The opening of a new market, that is, a market into which the particular branch of manufacturer of the country in question has not previously entered.

4. The conquest of a new source of supply of raw materials or halfmanufactured goods.

5. The carrying out of the new organization of an industry, like the creation of a monopoly position (for example through thrustification) or the breaking up of a monopoly position.

More or less every article or book about innovation and entrepreneurship uses this citation from Schumpeter's book or uses the Oslo Manual (2005) which is inspired by Schumpeter. From Schumpeter's point of view it is interesting to note how he emphasizes that the points 1-5 are linked together while many other writers using this typology are very occupied by looking at how to delineate one type of innovation from the other. By looking at how this typology links together the development of innovations in the company, we can first look at a new source of supply or a new method of production or a combination of these two that for the company can be combined into a new good. This good opens a new market possibility which again may change the market organization of the industry. So if we follow Schumpeter's advice it is much more fruitful to see how the different types of innovations can be linked together than how it is possible to separate one from the other.

Schumpeter also has some reflections about why only a minority of business leaders can be entrepreneurs. Schumpeter has neither a developed theory of knowledge and knowledge creation, nor about conversion of tacit to explicit knowledge. Schumpeter talks more about intuition without going into much detail. But he also talks about what kind of qualifications an entrepreneur must have in

Informe Gepec, Toledo, v. 18, n. 2, p. 163-176, jul./dez. 2014 
addition to the skill of finding the right combinations. He emphasizes the ability the entrepreneur must have to cooperate with people and he also mentions the ability to withstand the resistance from the society. This resistance has at least two sources and the first comes from the firm that the entrepreneur tries to develop. Here the central point for the entrepreneur is to have his employees change routines. The routine concept is important to Schumpeter as well as the processes about how to change them. Routines are often founded in the existing economic rationality and culture but for the entrepreneur to be successful, the routines have to be changed.

One other type of resistance comes from the environment of the firm which can be tasks like the legal control of the firm for fulfilling standards of production and quality control. Another task is security of production and this is sometimes linked to employer's organization. It is quite interesting to notice that many of these types of resistance to entrepreneurial management that Schumpeter wrote about in the first decades of 1900's are still found in the research about innovative activities today. In the empirical part of this paper we analyze how an innovation causes changes in routines, knowledge level, knowledge transfer and personal relationships, and how this again may cause resistance in the organization.

From his works Schumpeter also saw the difference between what one could call economic combinations and technological combinations. The much used quotation about new combinations is the following:

"The carrying out of new combinations we call enterprise, the individuals whose function is to carry them out we call entrepreneurs", Schumpeter (1934, p. 74).

Linked to the concept of the economic combinations, Schumpeter makes the central point of view that the entrepreneur must also make a profit for the development to be called an innovation - the combination has to be an economic combination. If we look at this from today`s structure and development of the society, a number of questions can be asked. One may ask if we talk about profit in the short run or in the longer run. Many innovative companies have negative economic development the first years, and then are profitable after a number of years, and some with large profits. During that time the product, the process and the market may have changed considerably so the net profits are made because of new developments after what we first called the innovation.

Another argument is made about the level of profit and market prices compared to what society needs. We have examples that products from the private sector, for example in medicine and health care, are based on innovations which are not profitable in the private market. But then the public sector picks up and uses this in developed versions with zero profit pricing in public hospitals or health institutions and one can find that this adds to the surplus of the society. A third argument is that many innovations and entrepreneurial activities that are based on new combinations that fail. The new developments these failures create may be produced with profits that are not based on new innovations but on the failed ones. So there is no doubt that Schumpeter had an important and interesting point of view when he linked profit/economic surplus to the entrepreneurial activity and innovation. But how to measure and evaluate this is not so easy.

\section{Creative destruction}

Informe Gepec, Toledo, v. 18, n. 2, p. 163-176, jul./dez. 2014 
Before we get into a discussion about the next central concept from Schumpeter, creative destruction, it is important to be aware of the fact that Schumpeter did believe in capitalist production as the fundamental mode of production with private ownership, competition and the market as the central regulators of economic activity and distribution. Schumpeter fundamentally disagreed with the traditional (neoclassical) explanation about how the capitalist system developed. For his disequilibrium theory the concept of creative destruction was fundamental. In the book, "Capitalism, Socialism and Democracy", Schumpeter (1942/1950, p82) presents the concept of creating destruction:

"The opening of new markets, foreign or domestic, and the organizational development from the craft shop and factory to such concerns as U.S. Steel illustrates the same process of industrial mutation - if I may use that biological term - that incessantly revolutionizes the economic structure from within, incessantly destroying the old one, incessantly creating a new one. This process of creative destruction is the essential fact about capitalism. It is what capitalism consists of and what every capitalist concern has got to live in."

Schumpeter applies the concept of creative destruction at the firm level, on the industrial sector level and as a more aggregated term about economic development more in general. On the firm/technology level we can use the following example from industrial production of electronics in the 1970's. At the beginning of the 1970's we had two central competitors for the product of reel-to-reel tape recorders, one firm was Tandberg from Norway the other was Sony from Japan. The Norwegian company was putting a lot of resources into product development and being at the technological front when it came to quality and durability of the product. Sony also put in a considerable amount of resources to develop the product and one can say that in the early 1970's the technology from both producers was quite high compared to the use. During the later 1970s the cassette standard increasingly took over in the consumer market. The response from Tandberg was to develop the reel-to-reel product with higher quality and more sophisticated user possibilities. The Norwegian company went broke in 1979 while Sony survived being the leader for the new standard. Here we see how one company, the Norwegian Tandberg company, was not able to destroy the old ideas about how the product should develop and renew production in an innovative way. The Sony Company used resources to combine technology and market information in a new way so that they kept the technological level while utilizing the new standard that was in line with consumer demands.

When we apply the concept of creative destruction at the sectoral level we have seen several changes in sectoral technologies such as in the production of steel and other metals where one production sector has had to change their routines and production structure because of new technologies while at the same time destroying the old ways of doing production. We have also seen creative destruction applied on a more general level to the development of the economy and production of what is called the back office revolution of the IT technology. This started in the financial sector where they changed from more manual procedures for bookkeeping to electronic and IT based systems. Also the health sector has many examples like the change from X-ray equipment to MR systems. The conclusion is that the concept of creative destruction can be applied on many levels from one single product to the more fundamental changes of the economic system and societal production.

In a paper by Andersen et al. (2006) they talk about creative destruction as a sequence of events. First we have the initial equilibrium where the starting point is an

Informe Gepec, Toledo, v. 18, n. 2, p. 163-176, jul./dez. 2014 
economic system based on stable routine behavior. Then the initial equilibrium breaks down when innovators start up their enterprises based on new innovative products and processes, and combined with increased value added and/or reduced unit cost this produces a surplus, normally as a profit, for the society. This process of innovation also leads to the demand of new skills and new transfer of knowledge because of new routines. These innovations also lead to an upswing in the economy but the upswing will after some time fade out because the innovations also will sharpen the competitive process of the market.

This way of arguing was one of the bases for Schumpeter's conclusion about the wave movements of the economy. One argument that may make this situation a little more complicated is that there is no reason to assume that the innovations and start up of new enterprises in one sector will be coordinated with what happens in other sectors. Schumpeter was fully aware of the characteristics of market behavior that change in one sector could spread over to another sector fast, but could have very little effect in other parts of the economy.

\section{Mark I and Mark II of creative destruction}

Most writers commenting on Schumpeter say that he quite fundamentally changed his view on entrepreneurship and innovation from his earlier writings. This has been called Mark I (the earlier) and Mark II (the later), this discussion has been taken up, among others, by Breschi et al. (2000) and Van Stel et al. (2005). The Schumpeter Mark I can mainly be found in the book about "Development" and here Schumpeter assumed competition between firms with basically fixed behavior. This has the implication that firms that are not innovative and unable to reduce unit cost when they meet competition from innovative firms will go bankrupt. In what is called Schumpeter Mark II (developed in the book about "Capitalism") he forwards the notion that firms can be responsive to changes using resources within the firm and in cooperation with other institutions of society (like the public sector and research and development activities). This means that non-innovative firms are able to respond to changes made by more entrepreneurial firms. The Schumpeter Mark II is based on a change in the focus from smaller individual firms to larger corporations that have oligopoly or monopolistic competition.

There have been some attempts to analyze whether it is the Schumpeter Mark I or Schumpeter Mark II which is the main driver of the economy. These studies have been done for different production sectors and for different time periods and results and discussions can be found in Andersen et al. (2006). This analysis builds on the assumption that we can decompose productivity development in two types of changes where the first is called the selection effect based on the reasoning behind the Schumpeter Mark I model and the second is called an innovation effect based on Schumpeter Mark II.

\section{Case study}

The Danish chicken slaughter Danpo produces 190,000 chickens every day five days a week. In 2010/2011 the company started to test a system for classification and grading of chicken carcasses integrated in their chicken meat production. In 2012 the company invested in the equipment and made it operational as a part of the production process.

Informe Gepec, Toledo, v. 18, n. 2, p. 163-176, jul./dez. 2014 
The system called VTS 2000 is a fully automatic system for classification and grading of chicken carcasses delivered from $\mathrm{e}+\mathrm{v}$ Technology $\mathrm{GmbH}$ in Germany. The system is based on digital video image analysis. The major components are:

- The cameras

- The lamps

- Optical sensors

- Image analysis computers

- 2 stainless steel boxes with green back plates
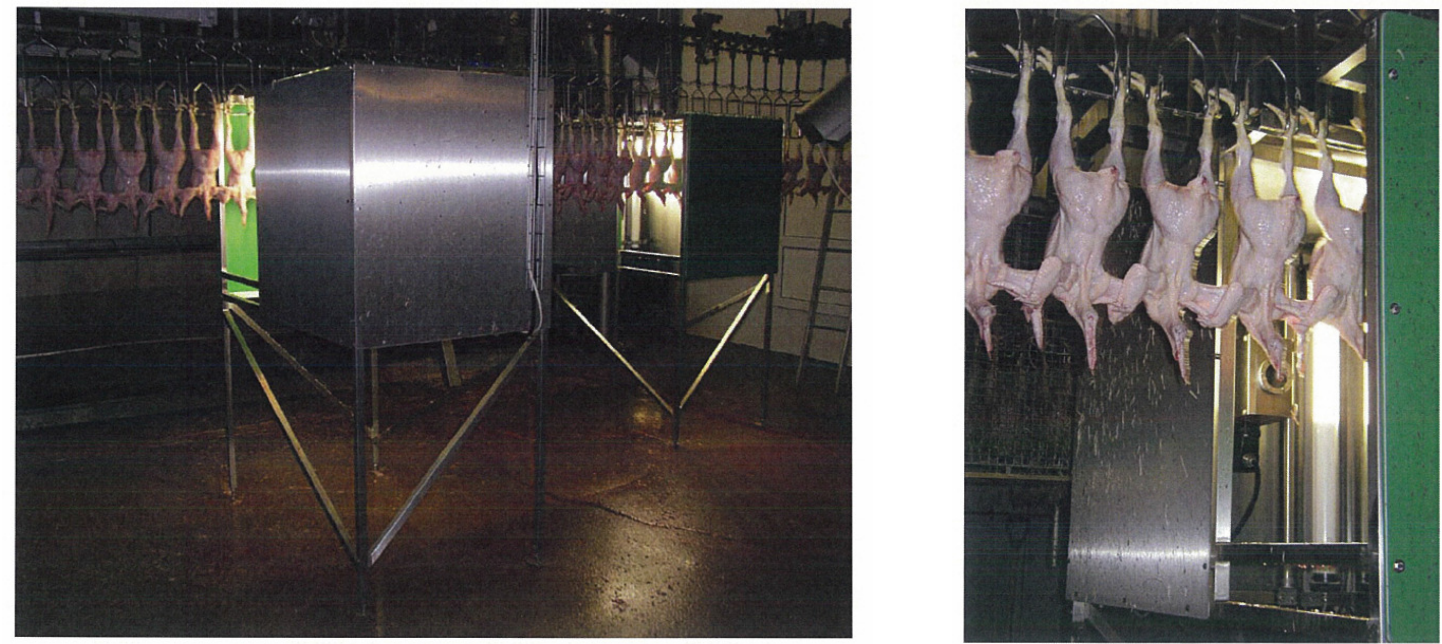

Picture 01 - Stainless boxes

Picture 02 - Box with camera and lamp

The logic behind the system is that the classification is done after the chickens are slaughtered, washed and hung on the transportation system inside the company. The transport line takes the chicken through a system of two boxes with cameras. Inside each box there is a high-speed video camera that captures images, one from front and one from the rear of each chicken. The computer program automatically analyzes each image and calculates carcass weight and chest fillet weight. The system also does other measurements and calculates several other parameters which will be explained later.

Before the introduction of the system, Danpo conducted a research project where they first sent the chickens through the VTS 2000 measuring system and after that did manual control; a report from these test procedures is DMRI, Danish Technological Institute, DMRI (2010). On the basis of these results and other tests using the system on 30,000 chickens the system is able to calculate the carcass weight with a precision of less than 1 gram, total fillet weight with a precision of less than 2 grams and calculating other parameters with satisfactory statistical test results.

The main reasons for the company to introduce the system were the following:

- To establish a new payment system between the company and breeders (the suppliers of chickens).

- Being able to give signals back to the breeder about health, feed and other parameters.

- Being able to use the system for better production planning and production monitoring inside the company.

- Being able to use the system for better market planning

Informe Gepec, Toledo, v. 18, n. 2, p. 163-176, jul./dez. 2014 
Two companies have considered installing this type of equipment in Denmark, Danpo and Rose Poultry. Danpo has a proactive approach to the use of the system and it has tried to exploit opportunities optimally. Rose Poultry has only looked at the possibilities but so far not bought or done tests with the system. One reason for this is that the system puts demands on both the knowledge and competence of those who actually use it and it also sets requirements for cooperation and knowledge transfer between departments within the company and with the company and outside partners.

This type of equipment based on scanning (taking pictures of animals) after they have been slaughtered has been used in the Danish food industry for many years, especially in pig and cattle meat production. The new challenge when it comes to chicken is that the software and classification systems are totally different since a chicken weighs only a fraction compared to pigs and cattle. And the speed of production per unit is very much faster and the system must be calibrated for photographing and scanning slaughter lines with a speed up to 12.000 chickens per hour. The company required accurate measurement results for at least $98 \%$ of the chickens on the transport line to be able to successfully use the equipment.

The initiative for the company to install the equipment came mainly from e+v Technology $\mathrm{GmbH}$ because of their marketing and their efforts to convince the company about the benefits and possibilities for increased productivity. Use of the equipment did not come as a result of demands from within the company or its own efforts to develop technology. The cooperation with the DMRI research institute was also crucial for the firm's decision to install the technology.

As described the technology includes cameras, lamps and light sensors, and boxes where the system is installed. Furthermore, all the camera systems are connected to a computer which is a standard PC with a relatively high performance, but not more advanced than a regular standard PC one can buy in a store. The distinctive and unique part of the system from the supplier is the software. It is the software that represents the innovative part of the technology. The software does the interpretation from the pictures which produce the results. The actual scanning is read by the software and places several points on the image which represents the different parts of the chicken, see Picture 03. 


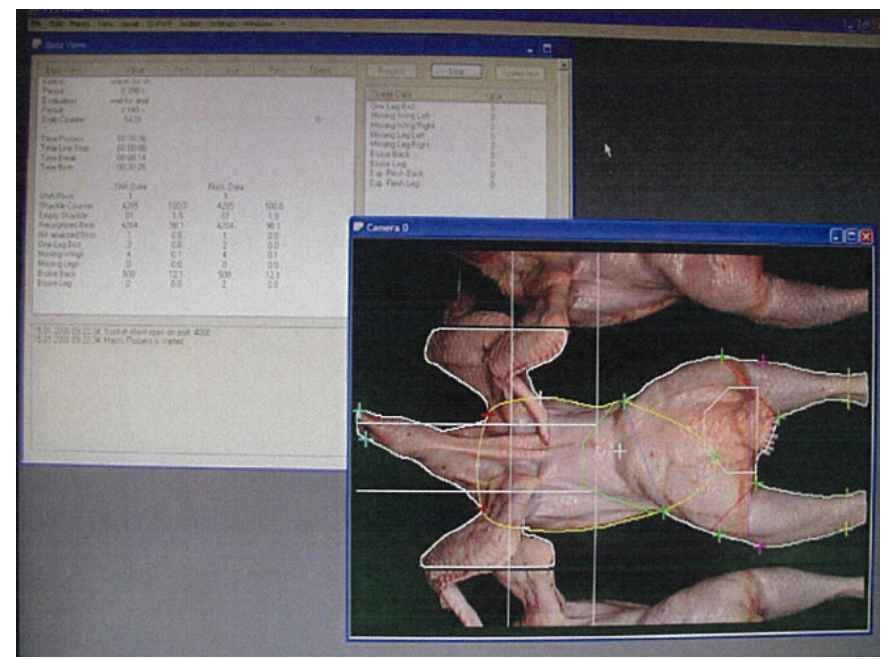

Picture 03 - Program window from computer

Behind these points lie routines in the software that provide an interpretation so that the system can calculate the weight, size, color and many other characteristics tied to the scannings which are used to calculate various interesting variables. For the system to work with the required accuracy, it must be calibrated. This is done by Danpo and they calibrate normally every night, after production for the day is completed. These are automated procedures that are supplied by the vendor as a part of the software. The programming code is kept secret by $\mathrm{e}+\mathrm{v}$ Company. The employees at Danpo only relate to the results and to check if there are any problems or discrepancies.

What is commonly known about the software is that it is based on a very large number of scannings of chickens. The vendor does regular upgrades of the software which is based on manual analysis of a large number of chickens. Based on these results the $\mathrm{e}+\mathrm{v}$ Company calibrates the algorithms that calculate the different variables. In short, one can say that the innovative technology lies in the construction of the computer programs, especially the construction of algorithms in the program and how these are updated and tested on actual data. The innovative part for the company is the use of the results and how this is done in relation to feedback to suppliers (breeders), in relation to the company's own production planning and quality control, and in relation to market planning.

The experiences that Danpo has had so far using the equipment show the importance of management functions with focus on the importance of understanding how the computer program, registration and algorithms work and how this is integrated in production. To get the best results it is important to have focus on transfer of knowledge within the company and to external partners. The use of the equipment has so far required no need for separate external training programs from the supplier other than what has been part of normal maintenance and upgrading.

Maintenance of the system has been limited in the sense that the equipment has had very few operational problems. On the other hand, to have a maintenance contract with the manufacturer is relatively costly compared to the value of the investment. A two-day maintenance visit by the manufacturer costs about $\$ 10.000$ euros. The price for the purchase of equipment was approximately 250.000 euros. The financing of the equipment was undertaken as a part of the company's capital expenditures for investment. It was not necessary to use special funds or other

Informe Gepec, Toledo, v. 18, n. 2, p. 163-176, jul./dez. 2014 
external financing since the purchase was financed by normal internal sources of investment capital.

It was the livestock department in the company that wanted the equipment the most because this department has the contact with individual farmers (breeders). One important task here is to find an operational mode for payments from the company to the breeder. Here calculation of weight is essential and the system now plays an important part in this.

It has been known for 3 - 4 years in the poultry industry in Scandinavia that Danpo has this equipment, but to the best of our knowledge no other companies have started to use the system as an integrated part of production.

As stated earlier, the three main indicators that the system calculates are carcass weight, chest fillet weight and a parameter called fillet yield. The experience the company has had so far is that the breeders with the highest quality also have the largest coefficient for fillet yield which is defined as breast fillet as a percentage of the total weight of the chicken. Other parameters analyzed are the following:

\section{1 - Ammonia combustion.}

The system analyzes and detects patches on the skin of the chicken which come from the ammonia in feces of chickens so that it looks like a burn.

\section{2 - Broken wing (s).}

Here the criteria are o or 1 , either the chicken has a broken chicken wing or it has not. An interesting observation here is whether the wing was broken before the chicken came to the company or if the wing is broken as part of the production process in the company.

\section{3 - Detection of chickens hanging by one leg only.}

During the manufacturing process the chickens are hung up on the transportation system and it is interesting to know how many are hanging by one leg only. This is detected by the image scanning and analysis by the software. This information is then used to calibrate and maintain the production system in the company.

\section{4 - Chickens with or without head.}

Normally the head of the chicken shall be removed before the chicken has come as far as the camera boxes on the production line. Chickens with heads are detected and registered by the scanning system. This is also an indication that there is a technical problem in the production system.

\section{5 - Injuries and stains.}

The analysis of the scanned images can also show if the chicken has damage or stains, this is detected as red or blue spots on the chicken. The interesting phenomena to observe in connection with this are if there is blood retention in the meat. The indicator of injury and stains is of greater interest primarily for the analysis of breast fillets and is an indicator of the health and welfare of the chicken more in general. 


\section{6 - Breast fillet indicator.}

This is a criterion which calculates the proportion of the breast fillet as a part of the entire weight of the chicken. This criterion is important in several contexts. The company uses this number as a quality indicator and this number is included in the formula on which the calculation of the payments between breeder and the company is settled. This is logical since breast meat has a much higher price than the rest of the chicken.

\section{The innovation in Danpo in a theoretical perspective}

What is described in the case study is what fits into Schumpeter's description and from the Oslo Manual that can be called a process innovation. This innovation has minor influence on how the product is received in the market by the consumers but is essentially motivated by improving the quality control, the speed of production and the payments and contracts with the breeders.

The new way of making product quality control by using IT technology adds a new aspect to the production process. The production is done in a technically new way which needs changes in routines, changes in knowledge level and transfer and allows an increase in the speed of production. The new technology is known from other types of meat production but the two novelty features are the speed of taking pictures and the size of the birds compared to other animals. The innovative aspect from a technical point of view lies in the software which operates the system.

One other interesting aspect with the case study is that there are two firms in Denmark producing white meat. These firms are about the same size and compete in more or less the same markets but the new quality control technology is only utilized in the Danpo company. From the financial point of view this is interesting to notice because the cost of buying, installing and running this technology is quite low compared to other machinery and capital costs. From the Schumpeter's point of view we see in this case an interesting example of creative destruction which means that people must change from human quality control, (which means people actually use their eyes to look at the chickens), to IT technology. This means that the company still must have employees doing quality control, but now looking at pictures and interpreting calculated results instead of looking at actual animals.

More or less all innovation studies emphasize that the innovation is context specific and this is the case also for the Danpo Company. But the interesting fact is that the other competing Danish company has a context which is quite equal to the Danpo Company but the innovation has not taken place in this company. We will not go further into the analysis of why the other company (Rose Poultry) has not introduced this technology, but just conclude that it was a strategic managerial decision to introduce this technology in the Danpo Company.

In the analysis of firms we find in the literature several possible approaches to the analysis of the strategies of firms like the market based, the resource based view of the firm and the dynamic capabilities view of the firm. In relation to this study the dynamic capabilities view of the firm seems most appropriate, one of the founding articles is written by Teece (2007). In this article Teece specifies three distinct processes for the firm to utilize its innovative developments:

- Sensing opportunities

- Seizing opportunities

Informe Gepec, Toledo, v. 18, n. 2, p. 163-176, jul./dez. 2014 
- Reconfiguring the resource base

In this case study two central features of firm management were emphasized:

- How the supply chain was working

- How the product quality control was working

- How quality control could be used for direct market information.

The market for food in recent years has developed in a way that the consumers are more conscious about who actually is producing the food they are eating. For different types of meat and cheese (and other products) it has been a market characteristic to tell the name of the actual producer and also show some pictures and indicate that this producer obeys ecologic standards, standards of animal health and so on. The market for white meat has not progressed to this extent because for most bulk production of chicken today it is more or less impossible to know the origin of the bird. The quality argument is often taken care of by the firm responsible for production, in this case Danpo.

In the Danpo case the market argument is that if there is a complaint or a problem with quality the company now is able to trace back the meat to the producer. So we can say that one argument for the innovation is how to relate the supply chain to product and quality control. The second main argument is that the speed of the quality control can be higher and the accuracy better. From the production point of view this is also an argument for reduced unit cost. With this new technology it is possible to better integrate the technology of quality control with the use of other technology (e.g. slaughter processing) to increase the speed of the production line.

A third use of the technology is for payments from the company to breeders. New technology makes it possible to accurately estimate the weight of the chicken reliably. Thus the information about weight of incoming chicken meat (from the breeder) is more accurate. The conclusion here is that the sensing of the possibilities originally came from the producer of the technology but through the research test project the firm was able to transform the information into the management system to analyze the possibilities.

The company conducted a project together with a research institution to go from sensing to seizing opportunities. The company had to be certain that the technology would work according to what the producer of the technology said. The total production line for white meat is dependent on every part being able to keep up the speed and continuity at a high level. It was essential that the quality control could be done even with a higher speed with the IT system compared to manual visual control.

In this project the seizing of opportunities together with the reconfiguration of the resources are linked together because the new technology presupposed new routines linked to all aspects of production. This is quite normal and to a large extent parallel with the reasoning by Schumpeter that an innovation process normally links together all aspects from types of innovation.

It is interesting to notice that the key features from the work by Teece (2007) are relevant in this case study using the concept of dynamic capabilities and the three keywords like sensing, seizing and reconfiguring the opportunities and actual processes within the firm. Another aspect of innovation theory that is also interesting and relevant in this connection is profitability. In this case the investment was quite

Informe Gepec, Toledo, v. 18, n. 2, p. 163-176, jul./dez. 2014 
low in monetary terms compared to other costs of the production process and the new technology seems to open new possibilities for increased profits. According to the company the investment will be paid off in 2-3 years, but the main argument from the company's point of view is that this technology opens up new possibilities to make profits in different ways both from the point of view of reducing unit cost of production and improving the market situation.

\section{References}

ANDERSEN, E. S., M. S. DAHL, B.-A. LUNDVALL and T. REICHSTEIN. "Schumpeter's process of creative destruction and the Scandinavian systems: a tale of two effects”, Paper for the DRUID Conference, 18-20 June, 2006.

BRESCHI, S., F. MALERBA, L. ORSENIGO. "Technological regimes and Schumpeterian patterns of innovation", The Economic Journal, 110, 338-410, 2000.

DMRI. "Vision classification and value-based payment of broiler chickens", Final report Project No. 1379720, Copenhagen: DMRI, 2010.

OECD. Proposed Guidelines for Collecting and Interpreting Technological Innovation. Oslo Manual, third (revised) edition, Paris: OECD, 2005.

SCHUMPETER, J. A. Theorie der wirtschaftlichen Entwicklung, Leipzig: Duncker \& Humblot, 1911.

SCHUMPETER, J. A. "New Translations: Theorie der wirtschaftlichen Entwicklung", American Journal of Economics and Sociology, 61 (2),405-37. Translations of parts of Ch.2 (pp. 103-07, 156-64) and Ch. 7 (pp. 525-48) by Markus Becker and Thorbjørn Knudsen, 1911 and 2002.

SCHUMPETER, J. A. The Theory of Economic Development: An Inquiry into Profits, Capital, Credit, Interest and the Business Cycle, London: Oxford University Press, 1934.

SCHUMPETER, J. A. Business Cycles: A Theoretical, Historical, and Statistical Analysis of the Capitalist Process, New York and London: McGrawHill, 1939.

SCHUMPETER, J. A. Capitalism, Socialism and Democracy, $3^{\text {rd }}$ ed. New York: Harper-Collins, 1942 and 1950.

SWEDBERG, R. Rebuilding Schumpeter's Theory of Entrepreneurship, Conference on Marshall, Schumpeter and Social Science, March 17-18, Hitotsubashi University, 2007.

TEECE, D., J., "Explicating dynamic capabilities: The nature and microfoundations of (sustainable) enterprise performance", Strategic Management Journal, 28, 1319-1350, 2007.

VAN STEL, A., M. CARREE and R. THURIK. "The effect of entrepreneurial activity on national economic growth", Small business economics, 24 (3), 311-321, 2005.

Informe Gepec, Toledo, v. 18, n. 2, p. 163-176, jul./dez. 2014 
Submetido em 23/o3/2014.

Sobre a autor

Aprovado em 09/07/2014.

\section{Knut Ingar Westeren}

Nord- Trøndelag University College, PB 7749 Steinkjer Norway.

Email: knut.i.westeren@hint.no 